UC-25

Reporting Date: Augusi 1974 Issued: September 1974

\title{
Impurity Effects on Low-Temperature Physical Pruperties of Uranium
}

by

Thomas A. Sandenavs

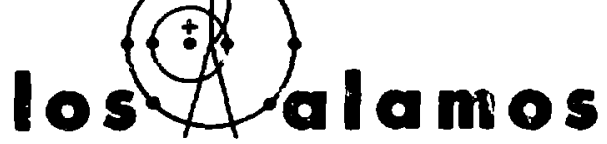

solemitio laboratory

of the University of Colifornio

lOS ALAMOS, NEW MEXICO 87544

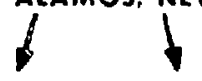

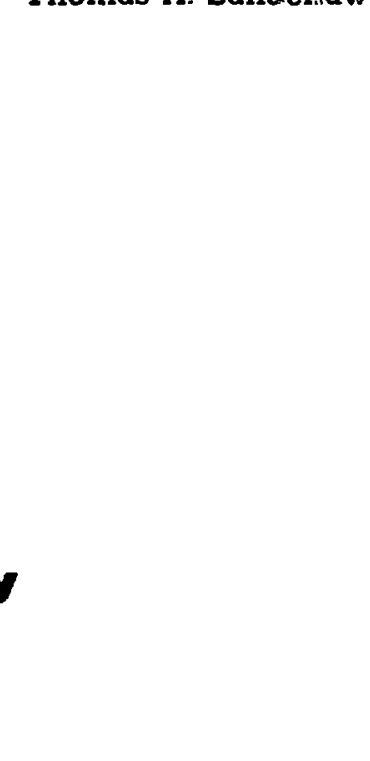


This report was prepared as an account of work sponsored by the United States Government. Neither the United States nor the United States Akomic Energy Commission, nor any of their employees, nor any of their ciontractors, subcontractors, or their employees, makes any warranty, express or implied, or assumes any legal liability or responsibility for the accuracy, completeness or usefulness of any information, apparatus, product or process disclosed, or represents that its use would not infringe privately owned rights.

In the interest of prompt distribution, this LAMS re port was nct edited by the Technical informazion staff.

Printed in the United States of America. Available from

National Technical Information Service

U.S. Department of Commerce 5285 Port Royal Road

Springfield, Virginia 22151

Price: Printed Copy $\$ 4.00$ Microfiche $\$ 1.45$ 


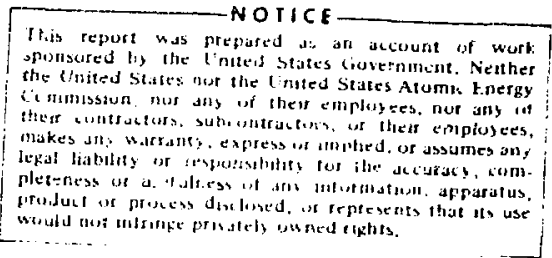

IMPURITY EFFECTS ON LOW-TEMERATURE PHYSICAL PROPERTIES OF URANIUTi

by

Thomas A. Sandenaw

\section{ABSTRACT}

Dips in low temperature heat capacity results for nominal high-purity uranium can be attributed to heat evolucion from the $U$ which is acting like a quenched marzensite. Because of tis martensite-like properties, the cooling rate through the $\beta \rightarrow \alpha$-phase transformation can affect the iowtemperature physical properties of $\alpha$-phase $v$.

Published information suggests that there will be no structural modification in very pure $U$ balow roum temperature. A single change, thought to be structural, is observed at $36 \mathrm{~K}$ in $U$ of nominal high purity. It is ascribed to Fermi surface-Brillouin zone boundary interactions. Phenomena observed at $250 \mathrm{~K}$ and $338 \mathrm{~K}$ are seemingly associated with the $36 \mathrm{~K}$ structural modification.

The appearance of as many as three low temperature heat capacity transitions, reported in this work for low-purity $U$, is attributed to impurity content. The observation of three low temperature transitions in single-crystai $U$, as reported in the literature, may be due to the grain-coarsening method of preparation of single crystals through S1 addition.

Heat capacity results presented here are considered to be a function of the impurity content and microstructure of a particular $U$ specimen at the time of $C_{F}$ measurament.

\section{INTRODUCT TON}

The major interest in the $\alpha$-phase of uranium in recent years has arisen because of the unueual disagreement concerning its superconducting transition temperature $\left(T_{c}\right)$. Reported values of $T_{c}$ have ranged from 0.15 to $1.5 \mathrm{k.}$ Most of the physical properties of $\alpha-U$, the allotropic form of the metal stable to $\sim 934 \mathrm{~K}$, show anomalous behavior below $350 \mathrm{~K}$ and in particular below $60 \mathrm{~K}$. There appears to be a timetemperature dependence In results for many of the measurements made on $\alpha-U$ at low temperatures, which 1s suggestive of an ordering phenomenon. $2,3,4$ The form of ordering may be complex, and various possibilities are discussed later. In addition, physical property results appear to have an impurity ${ }^{5}$ and microstructural ${ }^{6}$ dependence.

A number of transitions have been found below

$60 \mathrm{~K}$. The temperature at which they are observed seems to depend upon whether the $U$ test specimen has been prepared from high-purtty, polycrystalline metal or from single-crystal material. A single transition has been noted between 37 and $43 \mathrm{~K}$ when physical property measurements were rade on polycrystalline $U, 5,7$ but a temperature of $55-60 \mathrm{~K}$ was reported for what is probahly the same transition when thermoelectric power measurements were nerformed. Transitions at 23,37 and $43 \mathrm{~K}$ have been observed with single-crystal U specimens, ${ }^{8,9}$ but 
other workers have reported only a single transition at $43 \mathrm{~K} \cdot 10,11$ British workers ${ }^{12}$ found in their thermal expansion studies that they could suppress the $43 \mathrm{~K}$ transformation In polycrystalline $\mathrm{U}$ by quenching from above $50 \mathrm{k}$.

Higher temperature ranges reported for the appearance of what may be tine game phenomenon are as follows: $70-100 \mathrm{k}, 6,13250-280 \mathrm{k}^{2,4,10,13}$ and $325-350 \mathrm{~K} .14$

The authors of a recently published paper note that the $\beta \rightarrow a$ transformation in pure $v$ is peculiar and not, as yet, understood. 15 They note that the best evidence avallable for the transformation durIng a quench from the $B$-phase suggests a shear transformation analogous to the martensitic (diffusionless) transformation In U-Cr elloys. ${ }^{15}$ They aiso note, however, that the near-equillbrtum transfornation In pure $U$ (cooled very slowly through the transformation range) may be comparable to dilute $U-C$ alloy transformations and be diffusion zontrolled. The cooling rate of $U$ from the B-phase can thus affect the microstructure, because stacking faults, dislocations and quenched-In vacancles can be a function of the cooling rate as well as be influenced by stresses during martensitic transformations. Thus the quench and near-equilibrium transformations of normal purfty $U$ might be conparable to those of U alloys. Urantum ( $\alpha$-phase) is class:fied as a metallic alloy by Pearson, ${ }^{16}$ even in the absence of Impuricy elemen:s.

Berlincourt ${ }^{5}$ studied the low temperature Hall coefflctent, $(R)$, of two polycrystalline $U$ specimens of different purity. The higher purity specimen showed a sharp drop in Hall coefficient at $\sim 40 \mathrm{~K}$, while the coefficlent of reactor grade $u$ decreased slowly between $100 \mathrm{~K}$ and $60 \mathrm{~K}$ and dropped of $\mathrm{f}$ more rapidly below - $50 \mathrm{k}$. The value of $\mathrm{R}$ of the reactor grade sample became negative at $\sim 20 \mathrm{~K}$. Hts work thus shows the sensitivity of $U$ behavior to Impur1 ties.

A domain structure has been found In single crystals of $U$ by neutron diffraction measurements. 17 The domain size decressed by about a factor of two on cooling from room temperature to $10 \mathrm{~K}$. The preaence of dompins suggeste an antiphase ordered structure or a modulated stacling ordered structure.

Models for electronic changes during low temperature phase transitions have been discussed by
Smith and Fisher. 1 Three of these mechantsms were considered by Ross and $\operatorname{Lam}^{18}$ in attempting to explatn their magnetic susceptibilicy results for singlecrystal $\alpha-U$ : (a) locallzed $5 f$ electrons, (b) spindensity waves and (c) Ferml surface-Brillouin zone boundary Interactions.

The quegtion arises as to whether the low temperature physical property behavior of $U$ should be attributed only to any one or more of the suggested mechanisms or models, or whether it is also partially and significantly dependent on purity, microstructure or a form of order-disorder.

We have studied the low temperature heat capacity of polycrystali1ne ${ }^{235} \mathrm{v}$ and ${ }^{238} \mathrm{U}$ of known purfty with the hope that careful measurements on $v$ of different microstructures would clartfy the mechanlsms involved. It was further hoped that the phystcal property changes at $\sim 250 \mathrm{~K}$ and $325-350 \mathrm{~K}$ could be correlated with the presence or absence of low temperature phase transitions.

\section{SURVEY OF PRIOR RESEARCH}

A phase transition In $U$ at approximately $42 \mathrm{~K}$ was first reported by Fisher and McSkimi 10 from single-crystal elastic modull measurements. Schuch and Laquer ${ }^{19}$ had earlier shown a mintmum in the thermal expansion of polycrystalline $U$ at about this temperature, the minimum corresponding to a maximum in deneity.

$X$-ray analysis of single-crystal $U$ by Barrett et $a^{11}$ showed an anomaly at $43 \mathrm{~K}$, which was mantfested by a rapid increase of the $a_{0}$ and $b_{0}$ cell $d x-$ mensions below this temperature. The $c_{0}$ dimenston contracted on cooling to $43 \mathrm{~K}$ and decreased evt $\mathrm{n}$ more rapidly below this cemperature. They reported additional neutron diffraction reflections at lod temperatures which could have been Indicative of magnetic ordering, but susceptibility measurements by Ross and $\operatorname{Lam}^{18}$ tend to disprove this.

Fisher and Dever ${ }^{20}$ measured the elastic roduls of single crystals of $\mathrm{U}$ between 2 and $77 \mathrm{~K}$ and observed minima in the shear moduli at $18 \mathrm{~K}$ on cooling and at $22.5 \mathrm{~K}$ on heating. There was a high acoust:cal atcenuation at $T<43 \mathrm{~K}$. They concluded that there was a atructural phase change between 35 and $43 \mathrm{~K}$, and that the two phases had similar struccures. The phase change was found to occur at $37 \pm 2 \mathrm{~K}$. Indications for three phases below $50 \mathrm{~K}$ were reported 
by Sceinitz et al, 8 using semiconductor strain gauges on single-crystal $U$. Abrupt discontinuities in length were observed at 23 and $37 \mathrm{~K}$, whlle a sharp change in slope was seen at $43 \mathrm{~K}$.

Indications for the existence of low temperature phases in $U$ by heat capacity measurements have been reported. Lee $e_{i} a^{7}$ observed a small heat capacity anomaly at $\sim 43 \mathrm{~K}$ in h1gh-purity, polycrystalline $\mathrm{U}$. Crangle and Terporal ${ }^{9}$ measured the heat capacity of two polycrystalline specinens and one "pseudo single crysta1" of $U$ between 2 and $70 \mathrm{~K}$. An anomaly in $\mathrm{C}_{p}$ vs $T$ was seen in all of the samples at $43 \mathrm{~K}$, but only the "pseudo single crystal" exhiblted anomalies at 22 and $37 \mathrm{k}$.

Evidence for a phase transition at a temperature as high as $\sim 55 \mathrm{~K}$ was presented by $5 z e$ and Meaden. ${ }^{2}$ They measured the thermoelectric power, (S), of "unannealed" and annealed high-purity polycrystalline $U$ at varlous warming rates following various cool-down rates. Changes in slope of the $S$ vs $T$ curves were seen after fast or slow cooling rates if the subsequent warming conditions were dynamic. The changes of slupe were seen at approximately 20 , 30,40 and $55 \mathrm{k}$. Measurements taken under conditions approaching equilibrium, when there was a delay of 25 to 40 min preceding each measurement, gave $a$. smooth $S$ vs $T$ curve with a ininimum at about $50 \mathrm{~K}$ in bcth annealed and "unannealed" $\mathrm{U}$ and following either fast or slow cooling. Their interpretation was that very slow reheating pernitted transformation of retained, metastable a-phase to the properly stable low temperature phase for temperatures beluw $\sim 50 \mathrm{~K}$. Faster warming permits the formation of one or more metastable low temperature phases. They not only have shown how one can get evidence for slight anomalies at $-20,30$ and $40 \mathrm{~K}$ due to the possible existence of phase mixtures, but also have suggester another possible transition at 50-55 $\mathrm{K}$ under certai conditions.

The resiativity study of Arajs and Colvin ${ }^{3}$ al zo indicated resistivity shanges at $-50 \mathrm{~K}$, and espe. clally for a lower purity $U$ sample which had been held in 1iquid nitrogen at $~ 75 \mathrm{~K}$ for 8 days prior to the test. Holding for this length of time caused a decrease in the resistivity compared to that obtained upon normal warming from $-4 \mathrm{~K}$. The decrease persisted upon cooling unt $1148 \mathrm{~K}$ was reached, at which temperature the lower (conling) resistivity curve folned the upper (warming) rurve. Their work Indicates the importance of another temperature, $75 \mathrm{~K}$, and presenta possible evidence for a form of ordering in $U$ which takes place slowly in the virinity of this temperature.

The very slight dip in susceptibllity found by Fournfer ${ }^{4}$ between 80 and $280 \mathrm{~K}$ for polycrystalline $\alpha-U$ could also be considered as evidence for a form of ordering which was not wagnetic in character, but due onl: to structure. His work introduces another significant temperature for $\alpha-U$, namely $\sim 280$ K. Other sorkers have noted slight changes in $\alpha-U$ properties at this approxinate temperature. Rossn 13 reported that the longltudinal acoustical attenuatiun of U displayed a snall hump centered at $250 \mathrm{~K}$, whlle Sze and Meaden ${ }^{2}$ found a thermoelectric power anomaly at the same temperature. Fisher and McSkimin ${ }^{10}$ noted that the stiffness modulus, $c_{11}$, of single-crystal $\mathrm{U}$ changed anomalously between 78 and $573 \mathrm{~K}$ and had a maximum value at $265 \mathrm{~K}$.

Rosen $^{13}$ studled Young's modulus, shear moduli, acoustical at tenuation, adiabatic compressibility and $\theta_{D}$ behavior of $U$ containing 200 ppm impurities. Young's modulus showed a maximum at $100 \mathrm{~K}$ anc decreased with decreasing temperature to a minimum at $\sim 36 \mathrm{k}$. Armstrong et $\mathrm{a} 1^{6}$ studied the elastic moduli of the different phases of polycrystalline $L$, and of $a-U$ down to low temperatures to deternine the influence of crystal structure. They found that the elastic moduli of $\alpha-U$ were very sensitive to the degree of preferred grain orientation. The wide range in reported values for Young's modulus at

$70 \mathrm{~K}$, the temperature at which the modulus reaches a maximum, is shown in theis Fig. 3. The structural transition temperature of $37 \mathrm{~K}$ for $\mathrm{U}$ coincides with their temperature of the minimum in Young's modulus.

It was noted above that certain experimental results indicate the possibility of a form of ordering in $\alpha-U$. Welsbers and Quimby ${ }^{21}$ have reported that length, electrical resistivity and the elastic modulf all decrease with increasing crystallographic order, but that Young's modulus, which is a reciprocal function of the elastic constants, increases with increasing order. The Young's modulus (E) of $U$ increases with decreasing temperature and reaches a maximum at - $70 \mathrm{~K} .{ }^{6}$ This behavior is compattble with a form of order in $U$, and a variable degree of 
order attained would explain the difference in values observed for $\mathrm{E}$ at $70 \mathrm{~K}$.

Abnormal changes in the temperature dependence of certain shear modull and Young's modulus of $\alpha-v$ above $3.50 \mathrm{~K}$ have been noted by Fisher. ${ }^{14}$ He suggests that the causes for the high attenuation of the different shear modes above $325 \mathrm{~K}$ may be related to twinning dislocatlons, since twinning in $\alpha-U$ is very difficult to prevent. Twinning is a form of order, and twins can be formed in $U$ by deformation (or plastic strain) and even during heating and cooling, because of the anlsotropy of thermal expansion in the different crystallographic directions.

Douglass and Bronisz ${ }^{22}$ studied cold-worked and recrystallized $\alpha-U$ by transmission electron micros copy. The dislocation array, shown in their Fig. 3, for 3.5 per cent deformation by cold rolling, shows a few of the irregular closed loops similar to those which are seen as light or dark bands in the observation of antiphase boundaries. ${ }^{23}$

\section{ILI. SPECDMEN DESCRIPTION}

The specimens of ${ }^{235} \mathrm{U}$ and ${ }^{238} \mathrm{U}$, to be used for heat capacity studies reported here, were machined frow nominal high-purity buttons. These had been prepared by bomb reduction of the uranium tetrafluoride with calcium by the method of Kewish et al. 24 The metal reductions for the two materiala were done by different operators in different reduction furnaces, because of the radioactivity of the ${ }^{235} \mathrm{U}$. Chemical and spectrographic analyses of the original buttons are shown in Table I. Six specimens, 41.28 mm long and blunted $60^{\circ}$ triangular cross section at the ends, were machined from each button. The long1tudinal base of each specimen had a width of 8.687 mm and a top width of $3.175 \mathrm{~mm}$. The height was $4.763 \mathrm{~mm}$. The specimens were designed to $\mathrm{f} 1 \mathrm{t}$ snugly agalnst the separating walls of a six-vaned calorimeter can. The machined specimens were annealed for
$0.5 \mathrm{hr}$ at $873 \mathrm{~K}$ in vacuum and were alluwed to cool slowly overnight.

The experiment was designed to determine the influence of microstructure on the heat capacity of metal of each 1sotope. Thus, after the first set of measurements, the ${ }^{238} \mathrm{v}$ specimens were heavily cold worked by pressing the flat base of each bluntedged triangular specimen into a mold having a radlus of curvature of $12.32 \mathrm{~mm}$, the radius of the $1 \mathrm{n}$ terfor wall of the calorimeter can. The actual reduction in height of the triangular cross section was only from $4.763 \mathrm{~mm}$ to $4.547 \mathrm{~mm}$, but the major deformation was in shaping the $f$ lat base of each specimen into a partial cylindrical shape. The second set of $C_{p}$ measurments were made on the coldworked meta1.

A third set of heat capacity measurements was made on the ${ }^{238} \mathrm{v}$ spectmens after annealing for one hr at $873 \mathrm{~K}$, and a fourth set after an addit tonal heat treatment at $898 \mathrm{~K}$ for $144 \mathrm{hr}$.

After inftial measurements, the ${ }^{235} \mathrm{U}$ specimens were refrigerated in their sealed calorimeter can for one year. They were then remeasurei to determine the effects of self-irradiation damage. Differences in heat capacity should be due solely to microstructural changes.

The an.lealed ${ }^{238} \mathrm{U}$ specimens showed slight twinning after the first set of heat capacity measurements. The ${ }^{235} \mathrm{U}$ spectmens were not examined metallographically until after completion of all heat capacity measurements, but they also showed only slight twinning. This twinning could have arisen from stresses due to: (a) metallographtc pollshing. (b) temperature cycling or (c) the $\beta \rightarrow \alpha$-phase transformation during casting of the original button. The cold-worked ${ }^{238} \mathrm{U}$ specimens had a very high twin density and appeared to be deformed uniformly. The grain size was about the same in both the ${ }^{235} \mathrm{U}$ and ${ }^{238} \mathrm{U}$ spectimens, but of a duplex nature, 1.e., a mixture of large and small gyalns.

TABLE I

IMPURITY CONTENT OF ${ }^{235_{U}}$ AND OF $238_{\mathrm{V}}$

Element (ppm by mass)

${ }^{235} \mathrm{U}$

$238_{\mathrm{U}}$

$\begin{array}{lllllll}\text { Al } & \underline{M B} & \underline{\text { S1 }} & \underline{\mathrm{Ca}} & \underline{\text { Mn }} & \underline{\text { Fe }} & \underline{\mathrm{Co}} \\ 5 & 20 & 15 & <2 & 2 & 30 & - \\ 2 & 15 & 30 & <2 & 3 & 15 & <5\end{array}$

$\underline{N 1}$
20
20

Cu

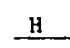

2

$<10$

$\begin{array}{lll}\text { N } & -\frac{\mathrm{C}}{-} & - \\ - & - & 50 \\ <10 & 75 & 50\end{array}$


The average size was about A.S.T.M. Std. No.-1 for all specimens. The surface of one of the ${ }^{235} \mathrm{U}$ specimens showed some recrystallization, which must have occurred during the original heat treatment, and was indicative of cold work caused by surface machining with a duIl tool. The fine grain size in the recrystallized areas was about A.S.T.M. Std. No. 8. There were a considerable number of oxide inclusions in the ${ }^{235} \mathrm{U}$ specimens, while the ${ }^{238} u$ specimens were relatively free of inclusions.

The heat capacity of a low-purity ${ }^{235} \mathrm{U}$ specimen had been investigated prior to the measurements on the nouinal high-purity specimens. The low-purity specimen was a cylindrical rod $6.35 \mathrm{~mm} 0 . \mathrm{D}$. and weighed $12.79 \mathrm{~g}$. The rod had been prepared by swaging and machining, and was then annealed for two hr at $898 \mathrm{~K}$. The major impurities were: $\mathrm{C}, 410$; $\mathrm{Si}$, 180; A.l, 40 and Fe, 35 ppm by mass.

The nominal high-purity 235 il specimens actually contalned 93.18 mass per cent ${ }^{235} \mathrm{U}$. The balance was assuined to be ${ }^{238} \mathrm{U}$ in calcuiating a gram formula mass (molar mass) of 235.2 to be used to derive the thermadynamic functions. The molar mass used to calculate the thermodynamic functions of ${ }^{238} \mathrm{u}$ was $238.0 \%$.

\section{EXPERIMENTAL}

Apparatius

The adiabatic-type continuous calorimetry system, including a description of the calorimeter cans, pli tillum resistance thermometer, temperature scale, 10-channel data $\log$ and timer-triggering circuit, has already been described in cousiderable detall. 25

Method

The nethod of making heat capacity measurements has also been described in detail previously. ${ }^{25}$ The six annealed ${ }^{235} u$ specimens were placed in a sixvaned calorimeter can and pushed saugly against the $60^{\circ}$ angled vanes. Copper shot was poured behiud each specimen to fill up the space in the calorimeter can to the top of the specimen. The $\mathrm{Cu}$ shot was used as a heat exchanger between the specimen and the extertor wall of the can and to insure that the ${ }^{235} \mathrm{U}$ specimens were kept in continuous contact with the separating vanes of the can. The masses of the $235 \mathrm{U}, \mathrm{Cu}$ shot ind calorlmeter can assembly were $131.732 \mathrm{~g}, 47.27 \mathrm{~g}$ and $119.580 \mathrm{~g}$, respectively.
The annealed ${ }^{238} \mathrm{U}$ specimens were inserted in an identical caiorimeter can in the same manner. Slightly more $\mathrm{Cu}$ shot was added, and the initial masses of the ${ }^{238} U$ specimens, $C u$ shot and calorimeter can assenbly were $136.140 \mathrm{~g}, 58.940 \mathrm{~g}$ and $119.580 \mathrm{~g}$, respectively.

Each calorimeter can, with its threaded cover tightly screwed into place, was evacuated through a Cu tube previously silver soldered into the cuver and back-filled six times with dry he gas before sealing with In+Sn solder. The two calorimeter can assemblies were again evacuated and back-filled six more tImes with dry He gas before clipping off each Cu tubulation and soldering its seam.

In tine second set of measurements, the coldworked ${ }^{238} \mathrm{v}$ specimens were replaced in the calorimeter can with their now rounded base against the outer wall of the can. Copper shot was poured into the narrower part of the volume of each of the six compartments, thus insuring heat exchange between a specimen and the vaned walls of the can. Heat capacities were then determined. The cold-worked specimens of ${ }^{238} \mathrm{U}$ were annealed for one hr at $873 \mathrm{k}$ and the $C_{p}$ vs $T$ was remeasured. The specimens were then given an additional $144 \mathrm{hr}$ anneal at $898 \mathrm{k}$, and the heat capacity was measured again. Heat capacity measurements were thus made on the ${ }^{238} \mathrm{v}$ in four different microstructural states.

Since the radioactive contamination of equipment was a problem with the ${ }^{235} U$, the specimens were held in the sealed can in a household-type refrigerator for one year in orier to evaluate the effects of self-irradiation damage. First measurements on the ${ }^{235} \mathrm{U}$ (after holding) were followed by others made at random intervals for a period of three months. The heat capacity results for the $235_{\mathrm{U}}$ were therefore representative of the annealed metal and for the metal after 12 to 15 months of self-irradiation damage. The microstructure in the damaged state should have been representative of the effects of vacancies and interstitials resulting, from Frenkel pair production for slightly over one year. Nothing unusial was seen by optical metallographic examination of the damaged ${ }^{235} \mathrm{v}$ after all measurements were completed. 
V. RESULTS

\section{${ }^{235} \mathrm{U}$ (Low-Purity Meta1)}

Heat capactty measurements were madc on $a$ swaged and anmealed. opecinen of low-purity ${ }^{235} \mathrm{U}$. Evidence for a phase transition was clearly seen at about $22 \mathrm{~K}$ fn the firat run of a serles, or for other runs when the spectmen had been warmed above $60 \mathrm{~K}$ sefore starting a run again at $4 \mathrm{~K}$. If an adiabat1: heat capacity run was stopped below $43 \mathrm{~K}$. then the peak originally at $22 \mathrm{~K}$ occurred at a higher temperature with each repeat run unt1l it was at 32 to $43 \mathrm{~K}$. Only a slight hump was seen at $\sim 19 \mathrm{~K}$. Slight peaklag was also seen from 60 to $70 \%$ whenever $a$ repeat run was continued above $43 \mathrm{~K}$. Measurements were discon:Inued after four sertes because there was no reproduclbility in the data, 1.e., no decision could be made as to a clear-cut phase transition temperature or if one truly existed. The peakfing in heat capacity seemed to depend on the processing. The thermoelectric power vs temperature curves for dynamic runs made on polycrystalline $U$, as reported by Sze and Meaden ${ }^{2}$ and shown on thetr Figs, 1 and 3, have the mult1ple peaks occurring at slightly different temperatures. These are like the $C_{p}$ vs $T$ data obtained with the low-purity ${ }^{235} \mathrm{U}$, which suggested several low temperature transitions.

\section{${ }^{238} \mathrm{U}$ (Polycrystalline)}

The $c_{p}$ vi $T$ data for ${ }^{238} \mathrm{U}$ specimens in the cast and annealed state and for the subsequent heavily cold-worked state are shown on Fig. 1 along with the data of Flotow and Lohr ${ }^{26}$ for high-purity ${ }^{238_{v}}$.

Curve A of Fig. 1 shows the best average of the low temperature data for the annealed polycrystalline $\mathrm{U}$, No evidence for low temperatise phases was detected by heat capacity measurements. The data were comparable, within experimental error, to those of Flotow and Lohr (curve $c$ ) up to $36 \mathrm{~K}$. Curve $\mathrm{A}$ diverged from curve $\mathrm{C}$ at $36 \mathrm{~K}$ and cont 1 nued at a lower $C_{p}$ level with Increasing temperature to about $250 \mathrm{~K}$. Curve $A$ and the data of curve $C$ were the same from 250 to $322 \mathrm{~K}$, where curve A turned upward to peak at $338 \mathrm{k}$. It returned to the curve of previousiy reported data at $352 \mathrm{~K}$. The apparent heat evolution between 36 and $250 \mathrm{~K}$ in curve $\mathrm{A}$ of $\mathrm{F} 1 \mathrm{~g} .1$ seems to be supporting evidence for some form of ordering in ${ }^{238} \mathrm{U}$, with posalble disordering at $338 \mathrm{~K}$.
Curve B, Fig. 1, Indicates an entirely different behavior for the heavily cold-worked metal. Although some runs showed dips between 38 and $45 \mathrm{~K}$ and between 45 and $50 k$, the majortty of the data was the same as that for curve $C$ within experimental error up to $50 \mathrm{~K}$. Above this temperature, the data for curve $B$ are higher than those for curve $C$, but the two curves colnclde again at $\sim 175 \mathrm{k}$. The data for the cold-worked otal, curve $B$, were quite consistent wth those of curve $\mathrm{C}$ from $175 \mathrm{~K}$ up to $350 \mathrm{~K}$.

The cold-worked ${ }^{238} \mathrm{U}$ specimens were annealed for one hr at $873 \mathrm{~K}$ and remeasured. The $C_{p}$ vs $T$ curve for the specımens in this microstructural state was similar to curve $C$ up to $50 \mathrm{~K}$, where it dipped slf.ghtly. Repeated runs yielded a wide band of data beiween $100 \mathrm{~K}$ and $373 \mathrm{~K}$ due to

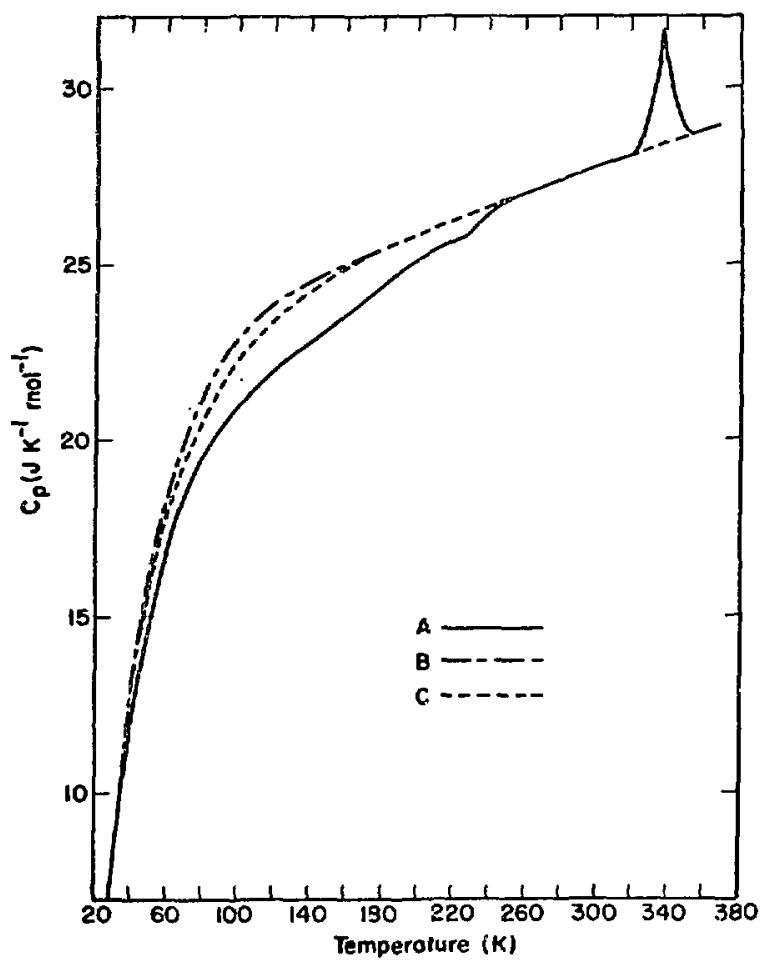

F1g. 1. Heat capac1ty ys temperature for nominal high-purity ${ }^{238_{U}}$ in different microstructural states. (Smoothed curves.) Comparison with 238 data of Flotow and Lohr. 26 A. Machined from reduction button and annealed $0.5 \mathrm{hr}$ at $873 \mathrm{~K}$. B. Specimens descrlbed under (A), but heavily cold worked. C. Results of Flotow and Lohr. (Swaged rods annealed $0.5 \mathrm{hr}$ at $873-923 \mathrm{k}$.) 
TABLE II

SMOOTHED ENTROPY VALUES FOR 238 U IN DIFFEREKT MICROSTRUCTURAL STATES

(Molar mass $\left.=238.07 \mathrm{~g} \mathrm{Mole}^{-1} ; \mathrm{Cal}_{\mathrm{th}}=4.184 \mathrm{~J}\right)$

\begin{tabular}{|c|c|c|c|c|c|c|}
\hline \multirow[b]{2}{*}{$I(k)$} & $\begin{array}{l}\text { Cast and } \\
\text { annealed }\end{array}$ & $\begin{array}{c}\text { Cold } \\
\text { worked }\end{array}$ & $\begin{array}{l}\quad \text { Cold wo } \\
\text { Annealed } \\
1 \mathrm{hr} \text { at } \\
873 \mathrm{~K} \\
\end{array}$ & $\begin{array}{l}\text { plue } \\
\text { Annealed } \\
144 \mathrm{hr} \\
\text { at } 898 \mathrm{~K} \\
\end{array}$ & \multicolumn{2}{|c|}{$\begin{array}{l}\text { Data from } \\
\text { Flotow and Lohr } 26\end{array}$} \\
\hline & & & $\mathrm{JK}^{-1} \mathrm{Mole}^{-1}$ & & & $\mathrm{Cal}_{\mathrm{th}} \mathrm{K}^{-1} \mathrm{Mole}^{-1}$ \\
\hline 30 & 3.35 & 3.35 & 3.39 & 3.35 & 3.23 & 0.772 \\
\hline 50 & 9.37 & 9.50 & 9.67 & 9.67 & 9.46 & 2.261 \\
\hline 70 & 14.98 & 15.52 & 15.48 & 15.48 & 15.34 & 3.666 \\
\hline 90 & 19.83 & 20.75 & 20.63 & 20.63 & 20.46 & 4.891 \\
\hline 110 & 24.02 & 25.23 & 25.02 & 24.98 & 24.92 & 5.955 \\
\hline 130 & 27.74 & 29.12 & 28.95 & 28.83 & 28.82 & 6.887 \\
\hline 150 & 31.00 & 32.63 & 32.51 & 32.22 & 32.28 & 7.715 \\
\hline 200 & 37.99 & 39.92 & 39.62 & 35.50 & 39.53 & 9.448 \\
\hline 250 & 43.72 & 46.19 & 45.73 & 45.73 & 45.40 & 10.851 \\
\hline 300 & 48.66 & 51.25 & 50.75 & $5 . .09$ & 50.36 & 12.037 \\
\hline 350 & 53.09 & 55.81 & 55.35 & 55.98 & 54.67 & 13.006 \\
\hline 273.15 & $46.07( \pm .08)$ & $48.58( \pm .24)$ & $48.03( \pm .24)$ & $48.33( \pm .20)$ & $47.78( \pm .08)$ & $11.42( \pm .02)$ \\
\hline 298.15 & $48.49( \pm .08)$ & $51.13( \pm .24)$ & $50.62( \pm .28)$ & $50.88( \pm . .5)$ & $50.21( \pm .08)$ & $12.00( \pm .02)$ \\
\hline 373.15 & $54.85( \pm .16)$ & $57.40( \pm .32)$ & $57.11( \pm .32)$ & $57.73( \pm .40)$ & $-\infty$ & -- \\
\hline
\end{tabular}

non-reproducible osclllations in the results. Thermodynamic function values were calculated for each run.

The ${ }^{238} \mathrm{U}$ spectmens were then annealed for an additional $144 \mathrm{hr}$ at $898 \mathrm{k}$. Measurements indicated that slight additional changes had taken place. The $C_{P}$ vs $T$ curve was essentially that of curve $C$, Fig. 1, up to $45 \mathrm{~K}$, where a slight dip occurred. Repeated runs again showed oscillations in results and gave $a$ wide band to the $C_{p}$ vs $T$ curve between 100 and $373 \mathrm{~K}$. All measurements after the $144 \mathrm{hr}$ anneal showed a silght consistent increase in $C_{P}$ above $300 \mathrm{k}$, when compared with the data for the other microstructural states.

The entropy values obtained from the low temperature heat capacity measurements on the ${ }^{238} U$ in four different microstructural states are shown in Table II. The data are compared with values reported by Flotow and Lohr ${ }^{26}$ for the same temperatures. The enthalpy values calculated from the same data are shown in Table III and are again compared with the data of Flotow and Lohr for the same temperatures.

\section{${ }^{235} \mathrm{U}$ (Polycrystalline)}

The heat capacity data for the ${ }^{235} \mathrm{U}$ (curve A) are compared with data of Flotow and Lonr (curve $C$ ) for ${ }^{238} \mathrm{U}$ on Fig. 2. Curve A shows the best average of the results obtained with the cast and annealed ${ }^{235} \mathrm{U}$ specimens approximately two months after machinIng and annealing. The curve starts dfpping diay frow curve $C$ at $36 \mathrm{~K}$. There is a change of slope in curve $A$ at $50 \mathrm{~K}$, and the curve returns to curve $\mathrm{C}$ at - $70 \mathrm{~K}$. The $C_{p}$ vs $T$ curve again dips away from curve $c$ beginning at $-70 \mathrm{~K}$ and returns again to that curve by $120 \mathrm{~K}$. No evidence for transitions below $36 \mathrm{~K}$ was seen by heat capacity peaking. The data were extremely consistent in all heat capacicy runs in the temperature ratige up to $70 \mathrm{k}$. Scatter In the data increased above $70 \mathrm{~K}$, but the $c_{p}$ vs $T$ curve obtained had a telatively narrow band width and nothing unusual was discernible from $120 \mathrm{~K}$ up to $373 \mathrm{~K}$.

Curve $B$ of Fig. 2 1llustrates the effect of self-irradiation damage in ${ }^{235} \mathrm{U}$ held at $-278 \mathrm{~K}$ for 12 months. The data for most runs started at $4 \mathrm{~K}$ fell on curve $c$ up to $40 \mathrm{~K}$. The curve fell away from curve $\mathrm{C}$ at $40 \mathrm{~K}$, crossed over it at $\sim 58 \mathrm{~K}$ 
TABLE III

SMOOTHED ENTHALPY VALUES FOR ${ }^{238} v$ IN DIFFERENT MICROSTRUCTURAL STATES

$$
\left(\text { Molar mass }=238.07 \mathrm{~g} \mathrm{Mole}^{-1} ; \mathrm{Cal}_{\mathrm{th}}=4.184 \mathrm{~J}\right)
$$

\begin{tabular}{|c|c|c|c|c|c|c|}
\hline \multirow[b]{2}{*}{$T(K)$} & $\begin{array}{l}\text { Cast and } \\
\text { annealed }\end{array}$ & $\begin{array}{c}\text { Cold } \\
\text { worked }\end{array}$ & $\begin{array}{r}\text { Cold } \\
\text { Annealed } \\
1 \mathrm{hr} \text { at } \\
873 \mathrm{~K} \\
\end{array}$ & $\begin{array}{l}\text { Plus } \\
\text { Annealed } \\
144 \mathrm{hr} \\
\text { at } 898 \mathrm{~K}\end{array}$ & \multirow[t]{2}{*}{$\begin{array}{l}\text { Data from } \\
\text { Flotow and }\end{array}$} & $r^{26}$ \\
\hline & \multicolumn{4}{|c|}{$\mathrm{J}$ Mole $\mathrm{e}^{-1}$} & & $\mathrm{Cal}_{\mathrm{th}}$ Mole \\
\hline 30 & 71.13 & 71.13 & 73.20 & 75.30 & 70.46 & 16.84 \\
\hline 50 & 310 & 322 & 324 & 326 & 320.9 & 76.70 \\
\hline 70 & 649 & 678 & 669 & 669 & 672.3 & 160.69 \\
\hline 90 & 1033 & 1096 & 1079 & 1079 & 1081 & 258.44 \\
\hline 110 & 1452 & 1544 & 1515 & 1502 & 1526 & 364.61 \\
\hline 130 & 1900 & 2017 & 1987 & 1966 & 1992 & 476.21 \\
\hline 150 & 2356 & 2498 & 2464 & 2435 & 2477 & 591.94 \\
\hline 200 & 3565 & 3778 & 3728 & 3707 & 3739 & 893.57 \\
\hline 250 & 4828 & 5121 & 5054 & 5113 & 5055 & 1208.1 \\
\hline 300 & 6197 & 6502 & 6460 & 6552 & 6417 & 1533.6 \\
\hline 350 & 7636 & 7937 & 7899 & 8125 & 7825 & 1870.2 \\
\hline 273.15 & $5452( \pm 24)$ & $5761( \pm 40)$ & $5690( \pm 40)$ & $5761( \pm 48)$ & $5682( \pm 12)$ & $1358( \pm 3)$ \\
\hline 298.15 & $6143( \pm 32)$ & $6456( \pm 48)$ & $6410( \pm 40)$ & $6502(+48)$ & $6364( \pm 12)$ & $1521( \pm 3)$ \\
\hline 373.15 & $8276( \pm 40)$ & $8590( \pm 60)$ & $8548( \pm 48)$ & $8920( \pm 48)$ & $-\infty$ & $m$ \\
\hline
\end{tabular}

and showed slight peaking at $63 \mathrm{~K}$ and $75 \mathrm{~K}$. Above $85 \mathrm{~K}$, the $\mathrm{C}_{\mathrm{p}}$ data were consistently higher than those of curve $C$. The same tendency for oscillations in data was seen in the self-damaged $235_{11}$ as was seen with heavily cold-worked ${ }^{238} v$ that had been annealed for one $\mathrm{hr}$ at $873 \mathrm{~K}$. Repeated runs were made in order to get reasionably accurate thermodynamle function values.

The entropy values for the ${ }^{235} U$ in its two different microstructural states are compared in Table IV at several temperatures with data of Flotow and Lohr. The enthalpy daca ior the ${ }^{235} U$ at the same temperatures is listed In Table $V$ along with the enthalpy data of Flotow and Lohr.

Runs started at $75 \mathrm{~K} \quad\left({ }^{235} \mathrm{U}\right.$ and $\left.{ }^{238} \mathrm{U}\right)$

Several heat capacity runs were made with bath the ${ }^{23 j} \mathrm{U}$ and ${ }^{238} \mathrm{U}$ in their different microstructural states after lifuid nitrogen cooling and holding for 30 min at - $75 \mathrm{~K}$. All curves started at lower $C_{p}$ values than were observed with continuous adiabatic runs after additional 11quid He cooling. The $C_{p}$ vo $T$ curves for liquid $\mathrm{N}_{2}$ cooling and hoids at $\sim 75 \mathrm{~K}$ are shown for two different microstructures of both 1sotopes of $U$ of Fig. 3, along with the $C_{p}$ vs $T$ curve of Flotow and Lohr. Curve A, for specinens machined from cast and annealed ${ }^{238_{U}} \mathrm{U}$, is much lower than curve $C$ for specimens machined from cast and annealed ${ }^{235} \mathrm{U}$. Curves $A$ and $C$ are both apprectably lower than curve $\mathbf{E}$ of Flotow and Lohr. Cold working the ${ }^{238} \mathrm{U}$ raised the $C_{p}$ curve noticeably. The data for cold-worked ${ }^{238} \mathrm{U}$ are shown as curve $B$. It starts 1.5 percent abuve curve $E$, as compared to starting -6.5 percent lower than curve $\mathrm{E}$ in the cast and annealed scate.

The heat capacity curve for the ${ }^{235} \mathrm{U}$ held for 12 to 15 months is curve $D$ on Fig. 3. The curve for the self-damaged metal starts slightly below curve $E$ at $82 \mathrm{~K}$, but crosses over and goes above curve $B$ by $100 \mathrm{~K}$. Self-irradiation damage to ${ }^{235} \mathrm{U}$ for slightly over one year has an effect similar to cold working ${ }^{238} \mathrm{v}$ Insofar as 1ts effect on heat capacity behavior $1 \mathrm{~s}$ concerned.

The results of Flotow and Lohr ${ }^{26}$ were chosen as the reference curve for Figs. 1 through 3 and as reference values for Tableg II through $\mathrm{V}$ because their results were for truly high-purtty $U$ prepared in the standard manner, 1.e., swaged and then 


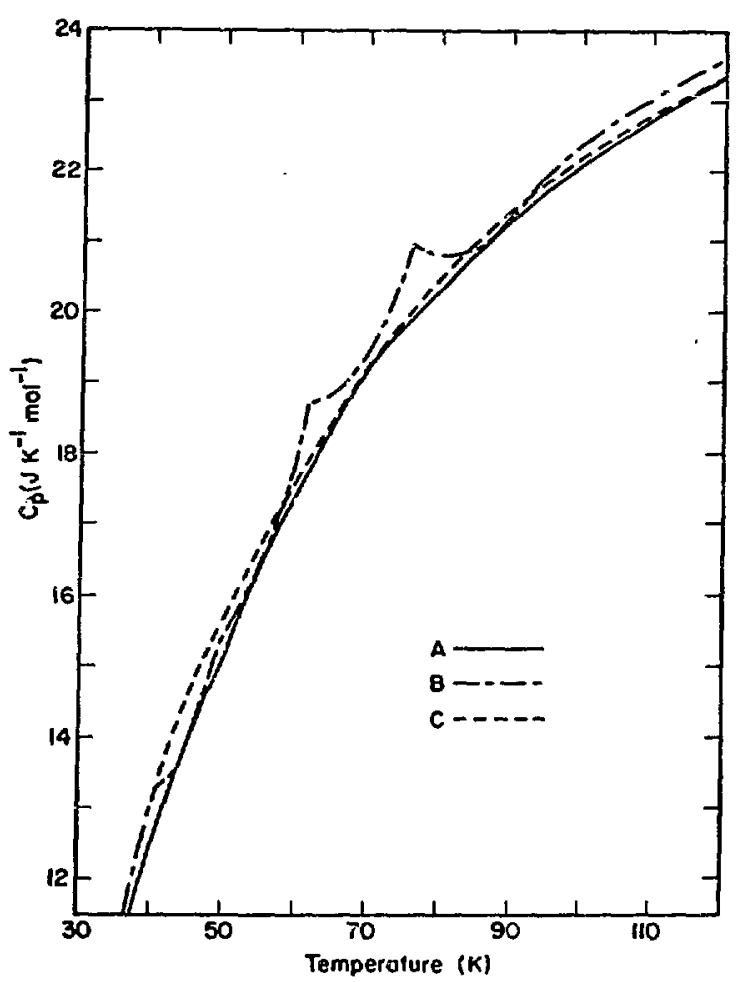

Fig. 2. Heat capacity ys temperature for noninal high-purity $235 \mathrm{U}$ in different microstructura1 states. (Smoothed curves.) Comparison with ${ }^{238} \mathrm{U}$ data of Flotow and Lohr. ${ }^{26}$ A. Machined from reduction button and annealed $0.5 \mathrm{hr}$ at $873 \mathrm{~K}$. B. Specimens described under $(\Lambda)$, but self-damaged by holding for 12 months at $\sim 278 \mathrm{~K}$.

c. Results of Flotow and Lohr.

annealed for $0.5 \mathrm{hr}$ at 873 to $923 \mathrm{~K}$. In addition the data from all microstructural states of ${ }^{235} U$ and ${ }^{238} \mathrm{U}$ matched their data within experimental error over several temperature ranges.

\section{DISCUSSION OF RESULTS}

Low Temperature Phases

Although the single-crystal $U$ studies of Steinitz et $a 1^{8}$ and Crangle and Tempora ${ }^{9}$ indicate possible phase changes at 22,37 and $43 \mathrm{~K}$, and Smith and Fisher ${ }^{1}$ report phases designated as $\alpha_{1}, \alpha_{2}$ and $\alpha_{3}$ from their high pressure work on single-cryst: . $\mathrm{U}$, it is difficult to reconcile anything but a silght transition at $\sim 36 \mathrm{~K}$ with the low temperature heat capacity results presented here for cast polycrystalline material. The heat capacity of the

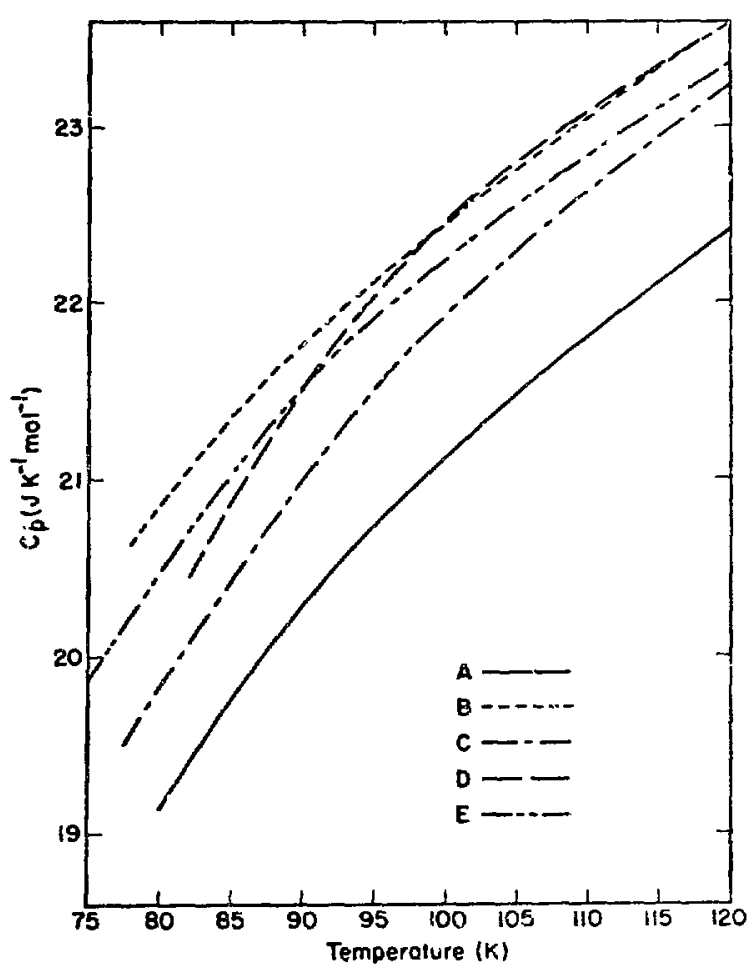

Fig. 3. Heat capacity ys temperature for nominal high-purity $235_{U}$ and $238 \mathrm{U}$ in different microstructural states. (Smrothed curves.) Deta taken after liquid nitrogen cooling followed by $0.5 \mathrm{hr}$ hold. A. Machined from $238_{\mathrm{U}}$ reduction button and annealed $0.5 \mathrm{hr}$ at $873 \mathrm{~K}$. B. Spectmens described under (A), but heavily cold worked." C. Machined from $235 \mathrm{U}$ reduction button and annealed $0.5 \mathrm{hr}$ at $873 \mathrm{~K}$. D. Specimens described under (C), but self-damaged by 12 months storage at $-278 \mathrm{~K}$. E. Results of Flotow and Lohr.

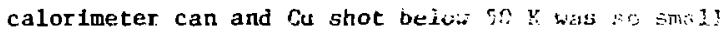
compared with that of the mass of the ${ }^{235} \mathrm{U}$ or $2 \mathrm{in}$. that it is unlikely that any first order transition would be missed under the adiabatic conditions of our experiment. There were no arrests in either the specimen temperature-time plots or in the shield temperature-time plots below $36 \mathrm{~K}$.

Confirmation For a single transition at - 4? $\mathrm{k}$, with supposedly very pure polycrystalline $u$, was presented by Lee er al ${ }^{7}$ trom their heat capacity study. The thermoelectric power study of Szc and Meaden $^{2}$ on high-purity polycrystaline $U$ indicated a transition at 50 to $60 \mathrm{~K}$ under conditions approachirg equ1librium. 
TABLE IV

SMOOTHED ENTROPY VALUES FOR ${ }^{23 S_{U}}$ IN DIFFERENT MICROSTRUCTURAL STATES

(Molar mass $=235.2 \mathrm{~g} \mathrm{Mole}^{-1} ; \mathrm{Cal}_{\mathrm{th}}=4.184 \mathrm{~J}$ )

$\mathrm{T}(\mathrm{K})$

30

50

70

90

110

130

150

200

250

300

350

2.73 .15

298. 15

373.15

\begin{tabular}{|c|c|c|c|}
\hline $\begin{array}{l}\text { Cast and } \\
\text { annealed }\end{array}$ & $\begin{array}{l}15 \text { months } \\
\text { self damage }\end{array}$ & \multicolumn{2}{|c|}{$\begin{array}{l}\text { Data from } \\
\text { Flotow and Lohr } 26\end{array}$} \\
\hline & $\mathrm{JK}^{-1} \mathrm{Mole}^{-1}$ & & $\mathrm{Cal}_{\text {th }} \mathrm{K}^{-1} \mathrm{Mole}^{-1}$ \\
\hline 3.26 & 3.51. & 3.23 & 0.772 \\
\hline 9.33 & 9.71 & 9.46 & 2.261 \\
\hline 15.10 & 15.64 & 15.34 & 3.666 \\
\hline 20.13 & 20.79 & 20.46 & 4.891 \\
\hline 24.56 & 25.27 & 24.92 & 5.955 \\
\hline 28.33 & 29.16 & 28.82 & 6.837 \\
\hline 31.71 & 32.68 & 32.28 & 7.715 \\
\hline 38.95 & 39.96 & 39.53 & 9.448 \\
\hline 44.77 & 46.15 & 45.40 & 10.851 \\
\hline 49.83 & 51.17 & 50.36 & 12.037 \\
\hline 54.22 & 55.73 & 54.67 & 13.066 \\
\hline $47.20(t .12)$ & $48.62( \pm .12)$ & $47.78( \pm .08)$ & $11.42( \pm .02)$ \\
\hline $49.66( \pm .16)$ & $51.00( \pm .24)$ & $50.21( \pm .08)$ & $12.00( \pm .02)$ \\
\hline $56.07( \pm .20)$ & $57.36( \pm .30)$ & $-\cdots$ & $-\infty$ \\
\hline
\end{tabular}

TABLE V

SMOOTHED ENTHALPY VALUES FOR ${ }^{235} \mathrm{U}$ IN DIFEERENT MICROSTRUCTURAL STATES

$\left(\right.$ Molar mass $\left.=235.2 \mathrm{~B} \mathrm{Mole}^{-1} ; \mathrm{Cal}_{\mathrm{eh}}=4.184 \mathrm{~J}\right)$

\begin{tabular}{|c|c|c|c|c|}
\hline $\begin{array}{l}\text { Cast and } \\
\text { annealed }\end{array}$ & $\begin{array}{l}15 \text { months } \\
\text { self damage }\end{array}$ & \multicolumn{3}{|c|}{$\begin{array}{l}\text { Data from } \\
\text { Flotow and Lohr } 26\end{array}$} \\
\hline \multicolumn{3}{|c|}{ I Mole $e^{-1}$} & $\mathrm{Cal}_{\text {th }}$ & $\mathrm{Mole}$ \\
\hline 70.29 & 74.48 & 70.46 & 16.84 & \\
\hline $3 \mathrm{i} .3 .4$ & 324.3 & 320.9 & 76.70 & \\
\hline 656.9 & 682.0 & 672.3 & 160.69 & \\
\hline 1063 & 1096 & 1081 & 258.44 & \\
\hline 1502 & 1540 & 1526 & 364.61 & \\
\hline 1962 & 2008 & 1992 & 476.21 & \\
\hline 2439 & 2489 & 2477 & 591.94 & \\
\hline 3686 & 3770 & 3739 & 893.57 & \\
\hline 4996 & 5134 & 5055 & 1208.1 & \\
\hline 6360 & 6569 & 6417 & 1533.6 & \\
\hline 7791 & 3012 & 7825 & 1870.2 & \\
\hline $5619( \pm 20)$ & $5803( \pm 24)$ & $5682( \pm 12)$ & $1358( \pm 3)$ & \\
\hline $6309(+20)$ & $6514( \pm 28)$ & $6364( \pm 12)$ & $1521( \pm 3)$ & \\
\hline $8431( \pm 25)$ & $8765( \pm 40)$ & -- & $\cdots$ & \\
\hline
\end{tabular}


Our heat capacity results showing a $22 \mathrm{~K}$ transition $\rightarrow$ low-purity ${ }^{235} \mathrm{U}$ suggesced that this cransition was due to impurities, princlpally $\mathrm{C}$ and $\mathrm{Si}$. other transitions at 32 to $43 \mathrm{~K}$ and from 60 to $70 \mathrm{~K}$ were also found for the less pure ${ }^{23 E} \mathrm{l}$. The swaging and annealing of our low-purity ${ }^{235} \mathrm{U}$ gave results surprisingly close to those presented by Crangle and Temporai ${ }^{9}$ for "pseudo single-crystal" $U$, except for the presence of a $C_{p}$ spike at $60-70 \mathrm{~K}$.

The $U$ spactuens of Flotow and Lohr ${ }^{26}$ had been prepared by swaging, which was followed by annealing for $0.5 \mathrm{hr}$ at $873-923 \mathrm{~K}$. Tt: specimens contained the following major impurities in ppm: C, 18; S1, 12 and 0,15 . They did not refort any low temperature phase transformation. This suggests that there w11l be no low terperatire structural change occurring in $U$ of sufficientiy high purity. There can be the indication of a low temperature structural modification, which appears at $-36 \mathrm{~K}, 1 \overline{\mathrm{f}}$ the $\mathrm{C}, \mathrm{SI}$ and 0 impurity contents are as high as shown in Table I (C, $50 \mathrm{ppm} ; \mathrm{Si}, 15$ to $30 \mathrm{ppm}$ and $0,75 \mathrm{ppm}$ ). The observation of low tesperature phases in $U$, and their rumber, appears tc depend upon metal purity and very possibyy on ine $\tau$ and $S i$ content.

FCC Phase in Urariug

$$
\text { A recart pepex by rwas and } \mathrm{Ban}^{27} \text { shows that }
$$
a fcc phase san exist $\therefore ; a=$ room temperature. It

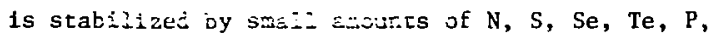
As, $S b, 3 \pm, C$ or $\mathrm{S}^{\prime}$. ment, the composition of this fec phase ranges between $\mathrm{U}_{20} \mathrm{~S}$ and $\mathrm{U}_{8} \mathrm{~S}$. If the atosile ratio of impurtty to $U$ was keft very low ( $U X_{0,1}$ ), the same fec $U$ phase appeared wizi aimost identical lattice parameters for most of tire eiements listed above. Only the proportion of $\alpha-U$ and fec $U$ differed from sample to sample.

The low-purity $235_{\mathrm{v}}$ investigated by heat capacity measurements contained $410 \mathrm{ppm} \mathrm{C}$ and $160 \mathrm{ppm} \mathrm{Si}$ by mass. The atomic per cent of these two elements combined would be $\sim \ldots .0$. Assuming that their effect would be similar to that for $S$, this could permit the presence of considerasle fcc phase mixed in with the predominantly $x$-phase, similar to the results of Tudja and ian, who obtained mixtures of these phases with sulfur compositions varyting fron only US 0.02 to $\mathrm{US}_{0.40^{\circ}}$
The fcc structurf for $U$, which has been shown to exist in the presence of certain impurity elements and at certain atomic ratios, may be really only a rediscovery. Early x-ray studies by McLennan and McKay ${ }^{28}$ on what may have been rather Impure metal suggested a cubic cell with $a_{0}=3.43 \AA$ (indexed at $15^{\circ}$ from Tudja and Ban). As the $U$ was prepared in c. purer and purer state, a monoclinfc structure was proposed, and this was finally followed by the orthorhmbic structure accepted today. ${ }^{29}$

The methods used in preparation of single crystals of $U$ have been discussed by Gittus. ${ }^{30}$ One of these methods, the grain-coarsening method, starts with high-purity $U$ to which a controlled amount of a suitable impurity such as $S 1$ is added by diffusion. ${ }^{31}$ Swaging and annealing follow the siltconizing heat treatment. If only a 10 to $20 \mathrm{ppm}$ overall increase in $S 1$ content was sufficient to prepare single crystals of $\alpha-u$, then the $s i$ content of Fisher's single crystals ${ }^{31}$ was slightly higher than listed in Table I for the noninal higb-purity ${ }^{235{ }^{\prime}}$ and $238 \mathrm{v}$.

The low-purity ${ }^{235} \mathrm{U}$ specimen wentioned above had a high $\mathrm{Si}$ content. It had been swaged and annealed. The latter two steps are part of the method used to promote grain growth for conversion to a single crystal. The heat capacity results for this low-purity ${ }^{235_{U}}$ indicated the presence of several low temperature phases including one with a transition at 19 to $22 \mathrm{~K}$. The appearance of the three low temperature phises may then be due to microstructural effects which were not eliminated by the annealing treatment, i.e., "banding" (Fisher's terminology) ${ }^{31}$ remaining from the swaging operation. Actually only small amounts of $\mathrm{Si}$ may be required to set up 1slands of a stacking fault orientation of the fcc phase in the presence of a regularly banded microstructure.

Although classified as orthorhombic, the $\alpha-U$ structure can also be described as deformed closepacked hexagonal. The resemblance is to that of a hexagonal metal in which successive basal planes have been shifted out of line with their neighbors. The structure has the appearance of a series of corrugations. It is realized today that stacking faults In metallic solid solutions play a considerable role in the explanation of properties such as phase 
morphology and crystallography of phase transformations, particularly in fcc and cph structures. A stacking fault consists of a sliver or lsland of mismatched material equivalent ro cph stacking in a fcc crystal and vice versa. Impurtties present in sufficlent quantity to stabilize the fcc phase of $U$ might play an Important role in the appearance of phases (Smith and Flsher) ${ }^{1}$ on application of pressure to supfosedly single-crystal $U$. The martensitic nature of the $B \rightarrow \alpha$-phase transformation in $U$ could Insure the presence of stacking faults. Increastng pressure might force the appearance of the structures which are known to be possible in $\mathrm{U}$ because a stacking. fault is a factor In the stabllity of one phase with respect to another.

\section{Domain Structure 1n S1ngle-E ysta1 U}

A domaln structure for single-crystal U was determined by the neutron diffraction study of Lander and Mueller. ${ }^{17}$ The size of the perfect domalns was reduced by about a factor of two in cooling frotn roon temperature to $11 \mathrm{~K}$. The1r work thus 1mplies a domain structure from $11 \mathrm{~K}$ up to abose room temperature.

A recent paper by Roltburd ${ }^{32}$ can help to explain the formation of domain structures in the presence of internal stresses $\ln \alpha-U$. The differences in the thermal dilation of the orthorhombic $\alpha-U$ struccure would induce severe strains in the metal on cooling or quenching to low temperatures. There could be formation of a new plase in order to lower the elastic energy of Internal stresses and the Eragmentation of the new phase into domains. Thert could also be the formation of ensembles of the crystals or regions of new phases arranged regularly inside the parent phase. This could thus explain the appearance of low temperature phases in $U$.

It is also possible that the deformed matrix of the swaged U rods, i.c., the banded structure of swaged meterial, may exist even after recrystallization into a single crystal. The presence of dislocations and stacking taults along with the banded array might allow a domain structure to form easily on cooling single-cryetal $U$ to low temperatures. The suggestion that swaging, il diffusion and recrystallization play a role in domain formation seems plaustble, One can specilate that the domain siructure present in single-crystal $U$ between $11 \mathrm{~K}$ and room temperature ${ }^{17}$ would be a modification of a long perlod stacking order. Stacking fault boundaries are a form of low energy boundary like antiphase boundarles which can modulate a close-packed structure. Thus a stacking modulated structure can become more stable than an unmodulated one. Modulated stacking ordered structures can even be stabiilzed in pure metals. 33

If suffictent $S t$ was present for formation of slivers of fcc phase in $U$, then this could be a way of introducing basal planes of fcc structure into the orthorbombic unit cell. This col ld be a source of stacking-order madulation as a modifled form of a long period superlattice 33 in $v$. Orthorhomblc modulated structures and thetr notation have been discussed by Pearsen. 34

\section{Structures Below $36 \mathrm{~K}$ in Polycrystalline $\underline{U}$}

The results reported here for polycrystalline ${ }^{235} \mathrm{U}$ and ${ }^{238} \mathrm{U}$, and shown on Figs. 1 and 2 , show that the heat capacity behavior below $\sim 36 \mathrm{~K}$ is the same regardless of microstructure. This requires an explanation, because the experinental results presented above Indicate that $c_{p}$ values found above $36 \mathrm{~K}$ are strongly dependent upon microstructure. The $c_{p}$ vs $T$ curves of F1gs. 1 and 2 for ${ }^{238} U$ and ${ }^{235} U$ watch that of Flotow and Lohr ${ }^{26}$ for high-purity $U$ below $36 \mathrm{k}$. No low temperature phases were detected by then a though their specimers were prepared by swaging and annealing. What one observes in the physical property behavior of $U$ below $36 \mathrm{~K}$ must then depend almost eatirely on purity. The implication of Flotow and Lohr's result is that there is no low temperature transition in highpurity $U$. It is thus doubtful if a domain structure can even exist in a-" of suffictently high purity when the specimen has been slowly cooled from the $\beta$-phase under diffusion-rontrolied conditions, because there will be a minimum of stacking faults.

\section{Urantum Martensites}

The heat evolution and 1ts effect on the "apparent" heat capacity of quenched martensites has recently been discussed for Iron-base alloys by Mogutnov and Shwartzman. ${ }^{35}$ Complextty of the aging processes, metastabllity of low cemperature precip1tates and influence of lattice imperfections were covered in their survey. They show that energy is evolved in raising the temperature of a quenched 
martensite. This causes dips in $c_{p}$ vs $T$ curves of the type visible in c'irves A of Figs. 1 and 2. There is thus the possibllity that $U$ can $b \in$ showing the physical property behavior of a quenched martensIte In its heat evolution below $250 \mathrm{~K}$.

The effects of impurities on the kinetics of the $B+\alpha$ transformation In $U$ have been discussed by Rechtien and Nelson. ${ }^{15}$ The low temperature transformation in J-Cr alloys is considered to be martensitic, while higher semperature transitions are balnitic and pearlitic. The three modes of transformations are thus analogous to those in the Fers? systems. The survey of Rechtien and Nelson suggests that the presence of small amounts of certain 1mpurities may be sufficient to impart the charactertstics of an alloy to $U$, and influence the martenstelc nature of the $\beta \rightarrow \alpha$ transformation.

Elements other than $\mathrm{Cr}$ might also cause the formation of metastable martensites of $U$. The consequence of this could be seen as low temperature Fhase transitions. The temperature at which a phase appeared could depend upon the metastable marcensitic character imparted to the $u$-phase by the Impur1ty elements present.

The heat capacity results shown in Figs. 1 through 3 suggest that the impuritles (listed in Table I) in the $235 \mathrm{v}$ and $238_{\mathrm{U}}$ spectmens may be sufficlent to cause an alloy-like behavior. The desomposition of a metastable martensitic alloy could give changes in the $C_{p}$ behavior which wouid be indicative of a phase transition, but it should not do it reproductbly on cooling from $373 \mathrm{~K}$ back to $4 \mathrm{~K}$ unless FS-BZ boundary interactions were involved. The reproducibility of appearance of the dip in $C_{p}$ vs $T$ curves at $36 \mathrm{~K}$ shown by the polycrystalline $\mathrm{U}$ isotopes should not be passible if the ${ }^{235} \mathrm{U}$ and ${ }^{238} \mathrm{U}$ were showing only the properties of a metastable martens lte.

Results of recently reported electron microscopy studies of tempered $\mathrm{Cu}-\mathrm{Al}$ martensites by Lefever and Delaey ${ }^{36}$ indicate the presence of an antiphase (long feriod superlattice) siructure. The heat evolution noted on warming quenched martensites could thus be indicative of the appearance of an antiphasc ordered structure and suggests that antiphase struitures may be quite common in martensites.

\section{Evidence for an Antiphase Structure in $\mathrm{U}$}

It has been noted above that small amounts of Impurity eiements may give $U$ an alloy-like character, and that Pearson ${ }^{16}$ classifies $\alpha-U$ as a metallic alloy. Ordering in an alloy, with domain formation, is required for appearance of an antiphase structure. It was developed in the intraductory sections that there was published informatlon suggesting ordering in $U$ at low temperatures. Barrett et a $1^{11}$ reported additional reflections in neutron diffracticn patterns of single-crystal $\mathrm{U}$. These could be indicative of a form of order that was not magnetic.

Evidence for a difference in the aegree of orderfng at $~-80 \mathrm{~K}$, dependent upon microstructure of the $U$, appears In the data of Fig. 3. The data shown on this figure were taken after holding for - $30 \mathrm{~min}$ In Ilquid $\mathrm{N}_{2}$ and seem to show the effect of some form of order. The curve for the ${ }^{238} \mathrm{U}$ (A) is lower than the one for ${ }^{235} \mathrm{U}(\mathrm{C})$ and both are lower than the data of Flotow and Lohr (E). Cold worling (curve $B$ ) or self damage (curve $D$ ) changed the heat capacity results drastically. The dislocation pile up from cold work must prevent che ordering of dislocations and stacking faults into an antiphase structure at the temperature where it would normelly appear. Small dips in $c_{p}$ of cold-worked ${ }^{238} U$ and selfdamaged ${ }^{235} 1 \mathrm{l}$ at higher temperatures could be from energy release due to step-wise ordering and give the wide band of data raporred above.

Sato and Toth $^{37}$ have established that the creation of new Brillouin zone boundaries at the Fermi surface can reduce the energy of the conduction electrons. This usually requires the creation of superperiods in the crystal lattice, and the superperiod arises by the perfodic introduction of antipuase boundaries. Complex superdislocation configurations can mak $₹$ up an antiphase domain structure. These complicated structures composed of extended dislocations, antiphase boundaries and stacking faults have been discussed by Marcinkowski et $a 1^{38}$ for the case of superlattice dislocations in $\mathrm{Cu}_{3} \mathrm{Au}$. Such a complicated antiphase structure should be expected in $U$ becalise of the nature of its martensitic $B \rightarrow \alpha-p h i s e$ transforiation.

The explanation for the drop-off in $C_{p}$ at $36 \mathrm{~K}$, as shown for cast and annealed polycrystalline ${ }^{238} \mathrm{v}$ by curve $A$ of Fig. 1, way be through the appearance of an antiphase structure at this temperature. Such 
a dip has been seen in heat capacity by Taylor et al ${ }^{39}$ In a Pu-Ga (\$-phase stabilized fcc) alloy on a first low temperature heat capacity run. A second low temperature run after self-irradiation damage to the specimen showed a double dip in heat capacity which has been interpreted by Sandenaw and Harbur 40 as evidence for an antiphase structure. They have also suggested tha' there is evidence for an antiphase stricture in Pu.

The $C_{p}$ vs $T$ curve for an antiphase structure shows a double dip due to energy release in domaln formation. The reason for this was explatned as follows by sykes and Jones ${ }^{41}$ for $\mathrm{Cu}_{3} \mathrm{Aul}$ : (a) the emergence of domains leads to a decrease in heat capacity throligh the liberation of energy by orderIng within domatus, (b) the liberation of energy falls off when the domains grow in size to contact each other, and the heat capacity rises toward a normal value and ( $c$ energy release starts on furcher warwing, which again causes a lowering of heat capacity. The second energy evolution is attributed to disappearance of domain boundaries as the size of the remaining domatns increases. Evolution of lieat again stops when only a single ordered domain remains. There would be a temperature range of order above the antiphase stricture range. This may be followed by another temperature range of disordering of atom: :

The heat capacity curve A of Fig. 1 does not show a clear-cuc double dip which can be attributed to an antiphase structure, but there is a change in curvature at $-145 \mathrm{~K}$ and at $-225 \mathrm{k}$. A slight maximum at $\sim 210 \mathrm{~K}$ is a possibility. Return of curve A to match curve $\mathrm{C}$ at $\sim 250 \mathrm{~K}$ followed by peaking at - $338 \mathrm{~K}$ ciuld be construed as reasonable evidence for an antiphase structure in the ${ }^{238} \mathrm{v}$. The end of the antiphase domain structure at $250 \mathrm{~K}$ could explain the anomalies noted in thermoelectric power, ${ }^{2}$ susceptibility, ${ }^{4}$ acoustical attenuation ${ }^{13}$ and stiffness modulus, $c_{11}, 10$ at this approxlmate temperature. The total breakup of a complicated order would account for the peaking at $\sim 338 \mathrm{~K}$ shown by curve $\mathrm{A}$, Fig. 1 , and would explain the high attenuation of different shear modes noted by Fisher. 14

An explanation has to be given as to why the $c_{p}$ vs $T$ curve for the ${ }^{235} \mathrm{U}$ did not show as low a $\mathrm{dip}$ as was seen with ${ }^{238_{\mathrm{U}}}$, although both specimens were machined from cast polycrystalline material of about the same purity and annealed identically. The partial answer may be in the stacking fault, dislocation and vacancy concentrations. These would affect ordering, especially if in antiphase or modulated stacking ordered structures. One of the operators invelved in bomb reduction of the $U$ isotopes pointed out that the ${ }^{235} \mathrm{U}$ button was cooled from the molten siate at a very slow rate. The ${ }^{238} \mathrm{U}$ button was cooled rapidly. Slow cooling through the $\beta+\alpha-$ phase transition could give a smaller stacking fault and dislocation concentration than rapid cooliug through the same transition, particularly since it is martensitic.

Domain hardening can be evidence of an antiphase structure in an alloy. This point is presented here because development of an increasing hardness in $\alpha-U$ on cooling below room temperature could be evidence for an antiphase structure. If there was indeed a maximum of order in $U$ at $\sim 70 \mathrm{~K}$, as suggested by Young's modulus measurements, then there could be a considerable decrease in hardness at the lower temperaturs and a much lower flow stress. Gittus ${ }^{42}$ shows the Brinell hardness of as-cast $U$ (500 ppm C) increasing down to $201 \mathrm{~K}$ where measurements ended. Leteurtre and Quere 43 note that slip becomes easy in $\alpha-U$ at a temperature between liquid $\mathrm{N}_{2}$ and room temperature, which is strongly dependent on the impurity content. These two bits of evidence seem to strengthen the argument for the possibility of both ordering and an antiphase structure below room temperature in U.

\section{FS-BZ Boundary Interactions in U}

If the dips in the $C_{p}$ vs $T$ curves for cast and annealed ${ }^{235} \mathrm{U}$ and ${ }^{238} \mathrm{U}$ shown on Figs. 1 and 2 were due to formation of martensite caused by the alloying effect of the 1mpurit:es, then the reproducibility in the levels of the urves would seem to be an impossibilicy. This u co only happen if there were FS-BZ boundary interactions which forced a reproducible antiphase ordered structure in the aartensite. If the impurity atoms present in $U$ car influence the phyalcal properties as greatly as they seem to do, then they must contribute to electron/atom or electrons/unit cell ratios of the resulting dilute alloys. Depending upon the Impurfty atom and its electron contribution, one could expect FS-BZ boundary interactions to show up at slightly different temperatures. Whether a structural modification takes 
place at $36,37,43$ or $55 \mathrm{~K}$ could depend entirely on the Impuricy atoms present and their concentrations. This would explain the variability in observed transition temperatures.

The suggestion given by Ross and Lam ${ }^{18}$ that

FS-BZ boundary interactions could explain the1r suscepibility results seems to give the best explanation for the low temperature behavior of $U$.

Factors Influencing Superconductivity

The above discussion suggests that there can be several factors influencing the temperature $\left(T_{c}\right)$ at which superconductivity is observed in $U$. The variability in superconducting transition temperature of $\mathrm{U}$ could depend upon: (a) Impurity content, (b) martensitic nature of an impurity alloy dependIng upon $\beta \rightarrow \alpha$-phase cooling rate, (c) the particular phase existing at $T_{c}$ under the circumstances (orthorhombic, cph or perhaps fcc), (d) a phase mixture under some conditions of cooling and

(e) domain size in a possible modulated stacking ordered structure.

Radiation Damage vs Cold Work

Lattice defects can be produced by quenching, cold work and particli: bombardment. The latter would produce lattice defects in ${ }^{235} \mathrm{U}$ with its own $\alpha$-particle artivity. A comparison of the $C_{p}$ vs $T$ curves for cold-worked and self-damaged U, Figs. 1 and 2, indicates that the effects are very much alike in $U$ above 50 to $60 \mathrm{~K}$. The $C_{p}$ vs $T$ curves after cold work and self damage are higher than in their original cast and annealed state. Th1s also shows up in Fig. 3, but the defects resulting from self damage give a different heat capacity response below $100 \mathrm{~K}$ than defects produced by cold work.

Thermodynamic Function Values

The heat capacity behavior shown in Figs. 1 through 3, for the cast and annealed $U$ isotopes, is most likely representative oniy of metal with the impurity content shown In Table $I$. Higher concentrations of $\mathrm{C}$ and $\mathrm{Si}$ (as well as other elements 1ike Cr) may change the martensitic character of the dilute alloy formed and give deeper dips in a $C_{p}$ vs $T$ curve. The chermodynamic function values listed in Tables II through $\mathrm{V}$ may be only representative of the ${ }^{235} \mathrm{U}$ and ${ }^{238} \mathrm{U}$ in the presence of the impurities indicated.
The entropy values for the ${ }^{238} \mathrm{U}$ in the vartous microstructural states are shown for several temperatures in Table II. The entropy at $298.15 \mathrm{~K} 1 \mathrm{~B}$ lower for the cast state by $1.72 \mathrm{~J} \mathrm{~K}^{-1}$ Mole $\mathrm{M}^{-1}(3.4$ percent) than the value reported by Flotow and Lohr, ${ }^{26}$ but the $S^{\circ}(298)$ vaiue for the cold-worked state is $0.92 \mathrm{~J} \mathrm{~K}^{-1}$ Mole $\mathrm{e}^{-1}$ (1.8 percent) higher. Annealing the cold-worked ${ }^{238} \mathrm{U}$ lowered the $\mathrm{S}^{\circ}(298)$ value by one percent and the $144 \mathrm{hr}$ anneal at $898 \mathrm{~K}$ seemed to cause an increase in $\mathrm{S}^{\circ}(\mathrm{T})$ particularly at $350 \mathrm{~K}$ and above. The same trend in entropy values was noted with the ${ }^{235} \mathrm{U}$ sample. The value of $\mathrm{S}^{\circ}(298)$, Table IV, for the cast and annealed ${ }^{235} \mathrm{v}$ was 1.1 percent lower than the value reported by Flotow and Lohr, but the value for the self-damaged state was higher by 1.6 percent.

The enthalpy values for the ${ }^{238} \mathrm{U}$ in the various microsiructural states are given in Table III as a function of temperature. The value of enthalpy at $298.15 \mathrm{~K}$ for cast and annealed ${ }^{238} \mathrm{U}$ is 4.8 percent lower than that for the cold-uorked state at the same temperature. Repeated annealing of the prevlously cold-worked state did not bring the value of $\left\{\mathrm{H}^{\circ}(298)-\mathrm{H}^{\circ}(0)\right\}$ down to the value reported for $298.15 \mathrm{~K}$ by Flotow and Lohr. The highest value of enthalpy at $298.15 \mathrm{~K}$ is shown by self-damaged $235_{U}$ (Table $V$ ).

Tables II and IV show that $S^{\circ}(298)$ values are comparable for cold-worked ${ }^{238} \mathrm{U}$ and self-damaged ${ }^{235} \mathrm{U}$, thus showing that the two different defect structures have a very similar effect on $c_{p}$ and must be quite similar. The difference in enthalpy between cold-worked ${ }^{238} \mathrm{v}$ and self-damaged ${ }^{235} \mathrm{U}$ at $298.15 \mathrm{~K}$ is $\sim 0.9$ percent.

\section{SUMMARY}

Dilute alloys of $U$ ford ar very low impurity levels. These may have a high ratio of $U$ atoms to impurity atum. Low concentrations of $\mathrm{C}$ and $\mathrm{Si}$ (among other elements) apparently have as great an ef izct on physical property behavior of $U$ as smal. amounts of $\mathrm{C}$ addition have on the physical properties of steels.

The $\beta+\alpha$-phase transformation of $U$ may either be martensitic or diffusion controlled depending upon cooling rate. The metal appears to have the properties of a martensite even in very dilute alloys. The cooling rate from the $\beta$-phase is thus very 
Important in the development of martensitic characteristics. The difference was noticeable in dips in $c_{p}$ vs $T$ curves of ${ }^{235} U$ and ${ }^{238} U$ when reduction buttons of the isotopes were cooled at different rates from the molten state.

There appears to be a type of crystallographic order in dilute $U$ alloys, and the simple model of order-disorder may not be applicable. It is suggested that the ordering is complex and such that an antlphase ordered structure or a modulated stacking ordered structure is formed. These different ordered structures are postulated for $d 1 f$ ferent temperature ranges.

Evolution of heat with Increasing temperature is a property of quenched martensites. The dips in $C_{p}$ vs $T$ curves of ${ }^{235} U$ and ${ }^{238} U$ which were found experimentally could be explained by the martensit $\perp c$ nature of diluce $U$ alloys. It is instead postulated that the reproducibility of starts in heat capactity dips at $36 \mathrm{~K}$ and the reproductbility in levels of $C_{p}$ curves between $36 \mathrm{~K}$ and $250 \mathrm{~K}$ are more representative of the appearance of an antiphase ordered structure.

FS-BZ boindary interactlons are considered to be the source of transitions observed in low-purity $U$. It is sugrested that electron contributions frot tmpurfty elements present in dilute $U$ alloys affect the temperature at which low temperature structural modifications appear.

Heat capacity curves presented and the thermodynamic values tabulated for cast and annealed ${ }^{235} \mathrm{U}$ and ${ }^{238} U$ are considered to be only valld for metal with the impurity content 1isted. Complete conversion to an antiphase structure would require a much higher impurity concentration. The tendency towards a complex form of order can explain the wide band of $C_{p}$ vs $T$ data above $100 \mathrm{k}$ for self-damaged ${ }^{235} \mathrm{U}$ and for cold-worked and annealed ${ }^{238} \mathrm{U}$.

Several low temperature phases were noted in low-purity ${ }^{235} \mathrm{v}$ by heat capacity measurements. Inpurity elements known to stabilize a fcc phase of $U$ and the banding resulting from swaging are considered to be the sources of these low temperature phases.

The difference between $s^{\circ}(298)$ of cold-worked ${ }^{238} \mathrm{U}$ and $S^{\circ}(29 \%)$ for transition-free $U$ (Flotow and Lohr) is $0.92 \mathrm{~J} \mathrm{k}^{-1} \mathrm{Mole}^{-1}$. The difference between $S^{\circ}$ (298) values for cold-worked ${ }^{238} U$ and self- damaged ${ }^{235} \mathrm{U}$ (after 12 to 1.5 months) is only 0.13 $\mathrm{J} \mathrm{K}^{-1} \mathrm{Mole}^{-1}$. The difference in enthalpy values for cold-worked ${ }^{238} \mathrm{U}$ and transition-free $U$ (Flotow and Lohr) at $298.15 \mathrm{~K}$ is $92 \mathrm{~J} \mathrm{Mole}^{-1}$ ( $22 \mathrm{cal} \mathrm{MoIe}^{-1}$ ).

\section{ACKNOWLEDGEMENTS}

Thanks are due to M. C. Tinkle for supplying the ${ }^{238} \mathrm{~L}$ reduction button and to 3 . A. Kircher for supplying the ${ }^{235} \mathrm{v}$ button. Group CMB- 6 of the LOS Alamos Scientific Laboratory should be thanked for machining the specimens from the ${ }^{235} U$ button, for original annealing of both the ${ }^{235} \mathrm{U}$ and ${ }^{238} \mathrm{U}$ specimens and for metallography on the ${ }^{235} U$ spectmens. E. G. Zukas must be credited for cold working the ${ }^{238} \mathrm{U}$ specimens and for interpretation of photomicrographs from metallographic examination of both matertals. Thin sections were sliced of $\mathrm{f}$ of the ${ }^{238} \mathrm{U}$ specimens after each microstructural change by C. E. Olsen and he must be credited for final heat treatment of the ${ }^{238_{U}} \mathrm{U}$ spectimens after cold work. R. D. Relswig kindly examined the ${ }^{238} \mathrm{U}$ slices metallographically so that comparisons could be made between the different microstructural states. Apprectation must be expressed for many helpful suggestions made by $H$. H. Hill, C. E. Olsen and R. B. Gibney during discussions on Interpretation of results. Spectal tharks must go to E. G. Zukas for discussions on the metallurgical aspects of the problem.

\section{REFERENCES}

1. T. F. Smlth and E. S. Fisher, J. Low Temp. Phys. 12, 631 (1973).

2. N. H. Sze and G. T. Meaden, Plutontum 1930 and Other Actinidss, $W, N$. Miner, Ed., Nuclear Metallurgy, The Metallurgical Soclety, New York (1970), Vou. 17, Part 2, p. 974.

3. S. Arajs and R. V. Colvir, 3. Less-Comon Metals I. 54 (1964).

4. J. M. Fournier; C. R. Acad. Sct. (Paris), 271B, 1156 (1970).

5. T. G. Berlincourt, Phys. Rev. 114, 969 (1959).

6. P. E. Arwstro.18, D. T. Eash and J. E. Hockett, J. Nucl. Mat 1. 45, $211(1972 / 73)$.

7. J. A. Lee, P. W. Sutcliffe and K. Mendelssohn, Phys. Let $t$. 30A, 106 (1969).

8. M. O. Steinitz, C. E. Burleson and J. A. Marcus, J. Appl. Phys. 41, 5057 (1970). 
9. J. Crangle and J. Tempolal, J. Phys. F 3, 1097 (1973).

10. E. S. Fisher and H. J. McSkimin, Phys. Rev. 124,67 (1961).

11. C. S. Barrett, M. H. Mueller and R. L. Hitter man, Phys. Rev. 129, 625 (1963).

12. A. Hough, J. A. C. Marples, M. J. Mortimer and J. A. Lee, Phys. Lett. 27A, 222 (1968).

13. M. Rosen, Phys. Lett. 28, 438 (1968).

14. E. S. Fisher, J. Nuc1. Mat1. 18, 39 (1966).

i5. J. J. Rechtien and R. D. Nelson, Met. Trans. 4, 2755 (1973).

16. W. B. Pearson, The Crystal Chemistry and Physics of Metals and Alloys, Wiley-Interscience, New York (1.972), p. 764 .

17. G. H. Lander and M. H. Mueller, Acta Cryst. B26, 129 (1970).

18. J. W. Ross and D. J. Lam, Phys. Rev. 165, 617 (19(8).

19. A. F. Schuch and H. L. Laquer, Phys, Rev. 86 , 803 (1952).

20. E. S. Fisher and D. Dever, Phys. Rev. 170, 607 (1968).

21. L. R. Weisberg and S. L, Quimby, J. Phys. Chem Solids 24, 1251 (1963).

22. D. L. Louglass and S. E. Bronisz, Trans. AMME 227, 1151 (1963).

23. M. J. Marchinkowski, Mem. Scien, kev. Met. 69, $579(1972)$

24. R. W. kewish, R. J. Bard, J. P. Bertino, O. B. Fry, S. W. Hayter, F. I. Hill, B. L. Kelehner and A. W. Savage, Jr., Trans. AlME 215, 425 (1959).

25. T. A. Sandenaw and R. B. Gibney, J. Chen, Thermo. 3, 85 (1971).
26. H. E. Flotow and H. R. Lohr, J. Phys. Chem. 64, $904(1960)$.

27. M. Tudja and 2. Ban, Croatica Chemica Acta 45, 371 (1973).

28. J. C. McLennan and R. W. McKay, Trans, Roy. Soc. Can. 24, 1 (1930).

29. C. W. Jacob and B. E. Warren, J. Amer. Chem Soc. 59, 2588 (1937).

30. J. H. Gittus, Uranium, Metallurgy of the Rarer Metals-8, Butterworths, Washingt on (1963) p. 300 .

31. E. S. Fisher, Trans. AIME 209, 882 (1957).

32. A. L. Roitburd, Phys. Stat. Sol, (a) 16,329 (1973).

33. H. Sato, R. S. Toth and G. Honjo, J. Phys, Chem. Solids 28, 137 (1967).

34. Ref. 16, p. 98-100.

35. B. M. Mogutnov and L. A. Shwartzman, Thermochimie, Colloques Intern. du C.N.R.S. $\mathrm{S} \cdot \frac{201}{20}$ Paris (1972) p. 373 .

36. 1. Lefever and 2. Delaey, Acta Met. 20, 797 (1972).

37. H. Sato and R. S. Toth, Phys. Rev. 124, 1833 (1961).

38. M. J. Marcinkowski, N. Brown and R. M. Fisher, Acta Mat. 9, 129 (1961).

39. I. C. Taylor, P. F. T. Linford and D. J. Dean, J. Inst. Metals 96, 178 (1968).

40. T. A. Sandenaw and D. H. Harbur, J. Phys. Chen. Solids 35, 795 (1974).

41. C. Sykes and F. W. Jones, Proc. Roy, Soc, Lond, A157, 213 (1936).

42. Ref. 30, p. 331.

43. 3. Leteurtre and Y. Quere, Irradiation Effects in Fissile Materials, North-Holland Publishing Co.. Amsterdam (1972) p. 42 . 